\title{
MONARTICULAR TRAUMA AND RHEUMATOID ARTHRITIS
}

\author{
BY \\ MICHAEL KELLY \\ Melbourne, Australia
}

It is believed that trauma may precipitate a first attack of rheumatic fever, and it is obviously true that local trauma may give rise to chronic monarticular arthritis. Chronic polyarthritis is another matter, since it is a systemic disease; yet Smith (1932) analysed the histories of 96 patients with rheumatoid arthritis and found that six were precipitated by injuries, which in five cases were monarticular sprains. Pickard (1947) reported that seven out of 35 cases of rheumatoid arthritis in children had been precipitated by injury to a joint; in a series reported by Bille (1948) the proportion was three out of 65 children. Finney and others (1947) reported that monarticular trauma had precipitated an initial attack or a relapse in five out of 100 cases in the U.S. Army.

The work of a number of European writers, who have discussed this subject during the past 20 years, has been reviewed by Jonsson and Berglund (1949). Edström (1942) reported five cases of rheumatoid arthritis in which monarticular trauma seemed to be the sole precipitating factor, and accepted the view of Klinge (1934) that the polyarthritis is an allergic reaction to tissue damage.

Rydén (1943) analysed the histories of 900 cases, and in nineteen found that rheumatoid arthritis had been precipitated by injury to a joint, and had extended to other joints in less than 6 months. He believed that septic teeth or tonsils were partially responsible for the disease in fifteen cases; he concluded that trauma may affect anyone whose mesenchymal tissues are susceptible, through infection or other constitutional factors, to a hyperergic reaction, and that this condition of susceptibility may fluctuate in an individual patient and vary from patient to patient.

Jonsson and Berglund (1949) did not consider trauma as a cause of rheumatoid arthritis if the following six conditions had not been fulfilled:
(i) No previous history of rheumatoid arthritis.
(ii) Injury to previously healthy joint.
(iii) Joint painful or swollen soon after the injury.
(iv) No decrease in pain and swelling before involvement of other joints.
(v) Spread to other joints not too long delayed.
(vi) Certain diagnosis of rheumatoid arthritis.

Of 1,669 cases of rheumatoid arthritis reviewed, Jonsson and Berglund found in twelve that the first sign of rheumatoid arthritis had been precipitated by injury to a joint, and that other joints had been involved within the year. In seven of 
these cases, however, one or more of the conditions was not fulfilled, and in four the authors found evidence of infection which (they thought) explained the arthritis. Thus only one case remained, which they did not consider sufficient evidence to establish trauma as a possible cause.

Jonsson and Berglund submitted the traumatic aetiology of rheumatoid arthritis to a rigid and exclusive test, demanding unbroken continuity of symptoms, both in the injured joint and in the spread of the process to other joints, in a patient who has never had arthritis before. It is hardly logical, therefore, to dismiss the evidence when the result of the test is positive. The exclusive role of trauma having been proved in that one case, it must be allowed as at least an important factor in all twelve cases. Other relevant articles are listed in the Additional Bibliography and in Table I.

\section{Present Series of Cases}

That injury precipitates chronic polyarthritis, is amply confirmed by my own experience (Kelly, 1948, 1949, 1951). In more than fifty patients out of 600 personally observed, injury was the sole visible factor; but this study is confined to 32 patients in whom the first symptoms appeared immediately after an injury to a single joint not previously injured before. The joint remained painful and swollen, for periods varying from one week to two years, until a second joint was involved, and in most cases a number of joints were then affected in a short time.

Table II (pp. 310 to 315 ) shows the 32 cases in order of authenticity. Cases 1 to 11 are so recent and so well documented that there is no doubt about the continuity of symptoms. In Cases 12,13,14, there was a gap of a few days between the infliction of the injury and the appearance of arthritis. The possibility of error increases in Cases 15 to 32, as the histories reach back into the past. In each case, however, the patient cannot be shaken from a clear story of injury followed by polyarthritis without a break in the symptoms.

Possible complicating factors occur as follows:

(i) Multiple injuries (Cases 9, 10).

(ii) Possibility of infection through wounds (Cases 10,11, 24).

(iii) Additional damage to same joint (Cases 16, 18, 22).

(iv) Ulnar nerve lesions (Cases 15, 29).

(v) Constitutional predisposition. No. 13 had iritis in 1940, and his mother suffers from rheumatoid arthritis. No. 16 had had an intractable attack of sciatica in 1920, and his mother had suffered from severe rheumatoid arthritis.

In Cases 19, 22, and 28, it could be objected that the spread to other joints was too long delayed, and in Case 28 that the joints involved are too few. In Cases 7 and 8 the period of observation was perhaps too short; so that we do not know what other factors might have appeared by this time. In Cases 6 and 30 (injuries to the back) more than one joint could have been injured.

But these are not valid objections. Not one of them argues against the influence of trauma; rather do they help to explain it. The aetiology of rheumatism is multiple, and a synchronization of precipitating and predisposing factors is often required to set the unknown mechanism in motion, though sometimes a single injury to a single joint acts as the "trigger".

\section{Traumatic Rheumatoid Arthritis}

Thus we have a variety of rheumatism that may be called " traumatic rheumatoid arthritis "; its incidence as reported by previous workers and in the present series is shown in Table I. This type of rheumatic disease offers special opportunities for study, because it provides us with a human experiment, in which the disease 
TABLE I

INCIDENCE OF TRAUMATIC RHEUMATOID ARTHRITIS

\begin{tabular}{|c|c|c|c|c|c|c|}
\hline \multirow{2}{*}{\multicolumn{3}{|c|}{ Author and Date }} & & \multicolumn{2}{|c|}{ Cases of Rheumatoid Arthritis } & \multirow{2}{*}{$\begin{array}{l}\text { No. Caused } \\
\text { by Trauma }\end{array}$} \\
\hline & & & & \multirow{2}{*}{$\begin{array}{c}\text { No. } \\
65\end{array}$} & Remarks & \\
\hline Bille (1948) & & .. & .. & & $\begin{array}{l}\text { Children treated with } \\
\text { gold }\end{array}$ & 3 \\
\hline Cecil and Kamme & rer $(195$ & 51) & $\cdots$ & 100 & Aged patients & 5 \\
\hline Copeman (1936) & . & .. & .. & 12 & $\begin{array}{l}\text { Pulmonary T.B. } \\
\text { suspected }\end{array}$ & 2 \\
\hline Davison and othe & rs $(195$ & & .. & 13 & $\begin{array}{l}\text { Cases treated with } \\
\text { pregnenolone }\end{array}$ & 1 \\
\hline Edström (1942) & . & .. & $\ldots$ & 262 & Unselected & 5 \\
\hline Finney and others & $(1947)$ & &.. & 100 & Soldiers & 5 \\
\hline Garrod (1888) & $\cdots$ & .. & .. & 100 & Unselected & 3 \\
\hline Jonsson and Bergl & lund $(1$ & 1949) & $\ldots$ & 1,669 & Unselected & 12 \\
\hline Kuhns (1945) & . & . & .. & 3 & Monarticular onset & 1 \\
\hline Lockie and Norcr & oss $(19$ & 48) & .. & 28 & Children & 3 \\
\hline Myers (1951) & .. & .. & $\ldots$ & 10 & $\begin{array}{l}\text { Cases treated with } \\
\text { pregnenolone }\end{array}$ & 1 \\
\hline Nissen and Spence & er $(193$ & & .. & 4 & Patients who died & 1 \\
\hline Pickard (1947) & .. & . & .. & 35 & Children & 7 \\
\hline Ropes and Bauer & $(1945)$ & .. & $\cdots$ & 11 & Cases of atypical onset & 1 \\
\hline Rydén (1943) & .. & . & .. & 900 & $\begin{array}{l}\text { Workers' compensation } \\
\text { cases }\end{array}$ & 19 \\
\hline Smith (1932) & $\cdots$ & .. & .. & 96 & Unselected & 5 \\
\hline Present Series & $\cdots$ & . & $\ldots$ & 600 & Unselected & 32 \\
\hline Total & .. & .. & .. & 3,908 & & 106 \\
\hline
\end{tabular}

begins in a certain joint in response to a known stimulus, and spreads in a regular manner to other joints. It remains now to discover if traumatic rheumatoid arthritis differs in any way from the ordinary clinical picture.

Age.-The average age at onset is 40 , a little younger than that of the general run of patients; in 568 non-traumatic cases the mean age at onset was 42.5 years. In Rydén's series the mean age was 36 years, his patients being nearly all men who had been injured at work.

Sex.-In the larger series, the women outnumbered the men by two to one; but sixteen of the 32 traumatic cases were male-doubtless because men are exposed to trauma more than women. Sixteen of Rydén's nineteen industrial cases were men.

Clinical Picture.-From patient to patient, rheumatoid arthritis shows every possible 


\begin{tabular}{|c|c|c|c|c|c|c|}
\hline \multirow{2}{*}{$\begin{array}{l}\text { Case } \\
\text { No. }\end{array}$} & \multirow{2}{*}{$\begin{array}{l}\text { Sex and } \\
\text { Age (yrs) }\end{array}$} & \multicolumn{3}{|c|}{ Injury } & \multirow{2}{*}{$\begin{array}{l}\text { Latent } \\
\text { Period }\end{array}$} & $\underset{0}{\vec{B}} \mathbf{S}_{0}$ \\
\hline & & Joint & Date & Nature & & Order $\overline{0}$ \\
\hline 1 & $\begin{array}{l}\mathbf{M} \\
29\end{array}$ & R. knee & Oct., 1949 & Severe blow & $4 / 52$ & $\begin{array}{l}\text { L. knee, } \frac{O}{\bar{s}} \\
\text { L. shoulder } \\
\text { back, feet }\end{array}$ \\
\hline 2 & $\begin{array}{l}\mathrm{F} \\
18\end{array}$ & L. knee & Jan., 1948 & $\begin{array}{l}\text { Sprain while } \\
\text { dancing }\end{array}$ & $2 / 52$ & $\begin{array}{ll}\text { R. knee, } & \stackrel{0}{ } \\
\text { wrists, } & \overrightarrow{0} \\
\text { hips } & \end{array}$ \\
\hline 3 & $\begin{array}{l}F \\
28\end{array}$ & L. wrist & 1945 & Sprain & $4 / 12$ & 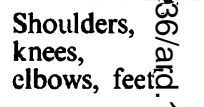 \\
\hline 4 & $\begin{array}{l}F \\
71\end{array}$ & R. knee & Oct., 1946 & Fall & $5 / 12$ & $\begin{array}{l}\text { L. knee, hậfts, } \\
\text { wrists } \\
\end{array}$ \\
\hline 5 & $\begin{array}{l}F \\
60\end{array}$ & L. knee & Apr., 1947 & $\begin{array}{l}\text { Severe } \\
\text { sprain; } \\
1 / 52 \text { bed }\end{array}$ & $2 / 52$ & Wrists, ank星 \\
\hline 6 & $\begin{array}{l}F \\
31\end{array}$ & $\begin{array}{l}\text { Lumbar } \\
\text { spine }\end{array}$ & Oct., 1949 & $\begin{array}{l}\text { Heavy fall; } \\
\text { tripped }\end{array}$ & $2 / 12$ & $\begin{array}{l}\text { Hands, wrises, } \\
\text { knees, } \\
\text { shoulders, feet, } \\
\text { ankles, hips } \stackrel{\mathbb{\Phi}}{-} \text {. }\end{array}$ \\
\hline 7 & $\begin{array}{l}M \\
31\end{array}$ & L. knee & Apr., 1943 & Blow & $2 / 12$ & 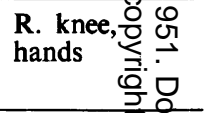 \\
\hline 8 & $\begin{array}{l}M \\
55\end{array}$ & R. ankle & 1941 & $\begin{array}{l}\text { Severe } \\
\text { sprain }\end{array}$ & $8 / 52$ & $\begin{array}{l}\text { L. ankle, } \\
\text { R. hand, } \\
\text { wrists, } \\
\text { L. elbow, } \\
\text { R. shoulder } \\
\end{array}$ \\
\hline 9 & $\begin{array}{l}M \\
36\end{array}$ & $\begin{array}{l}\text { L. thumb } \\
\text { (base) }\end{array}$ & July, 1949 & $\begin{array}{l}\text { Fracture: } \\
\text { slow union; } \\
\text { 10-ft. fall; } \\
\text { contusions }\end{array}$ & $3 / 12$ & 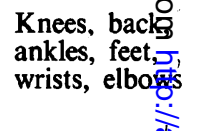 \\
\hline 10 & $\begin{array}{l}\mathbf{M} \\
31\end{array}$ & R. knee & Oct., 1947 & $\begin{array}{l}\text { Leg crushed; } \\
\text { abrasion }\end{array}$ & $6 / 52$ & $\begin{array}{l}\text { L. knee, feẹp } \\
\text { shoulders } \frac{\bar{x}}{3}\end{array}$ \\
\hline 11 & $\begin{array}{l}\mathbf{M} \\
37\end{array}$ & R. foot & Nov., 1948 & $\begin{array}{l}\text { Severe blow; } \\
\text { abrasion }\end{array}$ & $1 / 52$ & All joints \\
\hline 12 & $\begin{array}{l}M \\
40\end{array}$ & R. wrist & Oct., 1948 & Fall & $3 / 12$ & $\begin{array}{ll}\text { L. knee, } & \text { D } \\
\text { R. knee } & \text { O }\end{array}$ \\
\hline 13 & $\begin{array}{l}\mathbf{M} \\
27\end{array}$ & L. knee & Sept., 1947 & $\begin{array}{l}\text { Fall down } \\
\text { stairs }\end{array}$ & $4 / 52$ & $\begin{array}{l}\text { R. ankle, } \\
\text { R. knee, badsk } \\
\text { hips, wrists }\end{array}$ \\
\hline 14 & $\begin{array}{l}F \\
49\end{array}$ & L. elbow & Sept., 1948 & Painful blow & $5 / 12$ & $\begin{array}{l}\text { R. shoulder } \\
\text { L. shouldero } \\
\frac{\bar{D}}{\mathbb{D}}\end{array}$ \\
\hline
\end{tabular}


E II

MATIC RHEUMATOID ARTHRITIS

\begin{tabular}{|c|c|c|c|c|c|c|}
\hline \multirow{2}{*}{$\frac{\text { ead }}{\text { Rate }}$} & \multicolumn{4}{|c|}{ Involvement of Joints } & \multirow{2}{*}{ Later History } & \multirow{2}{*}{ Remarks } \\
\hline & Number & Size & Intensity & Duration & & \\
\hline Rapid & Few & Large & Severe & Transient & Remission in $9 / 12$ & $\begin{array}{l}\text { Wasted } \\
\text { quadriceps }\end{array}$ \\
\hline Rapid & Few & Large & Severe & Persistent & $\begin{array}{l}\text { Bedridden with } \\
\text { ankylosed hips }\end{array}$ & \\
\hline$\underset{(6 / 12)}{\text { Medium }}$ & Several & Large & Mild & Intermittent & $\begin{array}{l}\text { R. knee persis- } \\
\text { tently painful }\end{array}$ & Army nurse \\
\hline Rapid & Several & Large & Severe & Persistent & $\begin{array}{l}\text { Severe deformities } \\
\text { of knees and } \\
\text { wrists }\end{array}$ & \\
\hline$\underset{(5 / 12)}{\text { Medium }}$ & Few & Small & Mild & Transient & $\begin{array}{l}\text { History after Dec., } \\
1947 \text {, unknown }\end{array}$ & \\
\hline Rapid & Many & Both & Severe & Persistent & & $\begin{array}{l}\text { Still works } \\
\text { as a nurse }\end{array}$ \\
\hline Rapid & Few & Both & Mild & $\begin{array}{l}\text { Peri- } \\
\text { articular }\end{array}$ & $\begin{array}{l}\text { History after Aug., } \\
\text { 1943, unknown } \\
\text { (Army) }\end{array}$ & \\
\hline Rapid & Several & Large & Moderate & Intermittent & $\begin{array}{l}\text { History after } 1942 \\
\text { unknown }\end{array}$ & \\
\hline Rapid & Many & Large & Severe & Transient & $\begin{array}{l}\text { Remission in } 10 / 12 \text {. } \\
\text { Persistent back- } \\
\text { ache }\end{array}$ & \\
\hline Rapid & Several & Large & Moderate & Persistent & $\begin{array}{l}\text { Painful deformity } \\
\text { of shoulders, feet }\end{array}$ & \\
\hline $\begin{array}{l}\text { very } \\
\text { Rapid } \\
\text { (3 days) }\end{array}$ & Many & All kinds & Acute & Transient & $\begin{array}{l}\text { Persistent disability } \\
\text { of shoulders }\end{array}$ & \\
\hline $\begin{array}{l}\text { Slow } \\
(9 / 12)\end{array}$ & Few & Large & $\begin{array}{l}\text { Hydrarth- } \\
\text { rosis }\end{array}$ & Persistent & $\begin{array}{l}\text { History since } \\
\text { Sept., 1949, } \\
\text { unknown }\end{array}$ & \\
\hline Medium & Many & Large & Severe & Persistent & $\begin{array}{l}\text { Poker back, } \\
\text { kyphosis, lost } \\
70 \mathrm{lb} \text {. }\end{array}$ & $\begin{array}{l}\text { Con- } \\
\text { stitutional }\end{array}$ \\
\hline $\begin{array}{l}\text { Slow } \\
(2 / 12)\end{array}$ & Shoulders & only & Severe & Subsiding & $\begin{array}{l}\text { Slight stiffness of } \\
\text { shoulders }\end{array}$ & \\
\hline
\end{tabular}


TABL

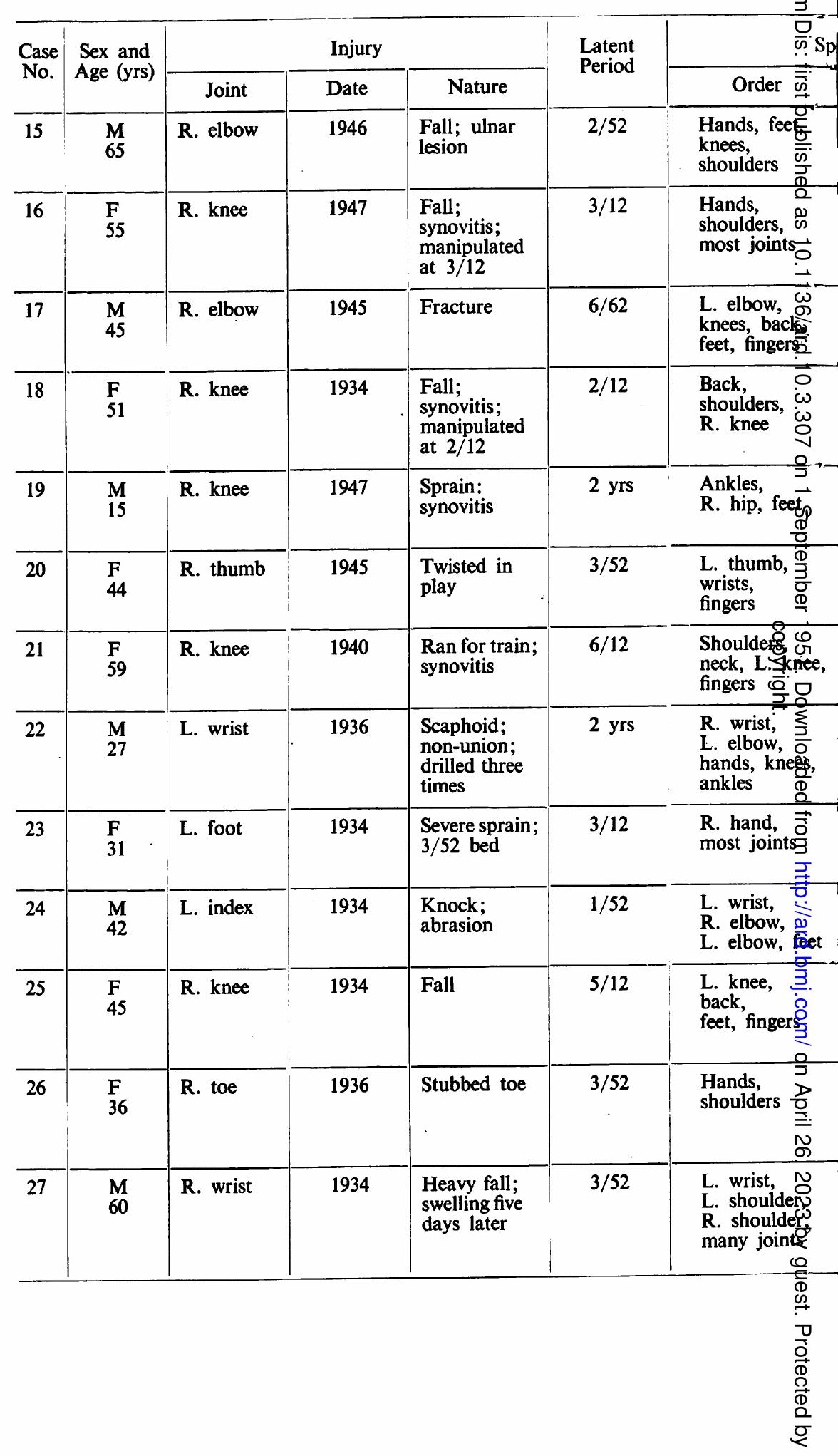


continued

\begin{tabular}{|c|c|c|c|c|c|c|}
\hline \multirow{2}{*}{$\begin{array}{c}\text { ead } \\
\text { Rate }\end{array}$} & \multicolumn{4}{|c|}{ Involvement of Joints } & \multirow{2}{*}{ Later History } & \multirow{2}{*}{ Remarks } \\
\hline & Number & Size & Intensity & Duration & & \\
\hline Rapid & Many & Both & Severe & Subsiding & $\begin{array}{l}\text { Painful L. shoulder, } \\
\text { deformities of } \\
\text { hands and feet }\end{array}$ & \\
\hline Rapid & Many & Both & Severe & Subsiding & $\begin{array}{l}\text { Flexion deformity } \\
\text { of knee }\end{array}$ & $\begin{array}{l}\text { Con- } \\
\text { stitutional }\end{array}$ \\
\hline Rapid & Many & Both & Severe & Subsiding & $\begin{array}{l}\text { Remission in four } \\
\text { years }\end{array}$ & \\
\hline Rapid & Several & Both & Moderate & Intermittent & $\begin{array}{l}\text { Residual pains in } \\
\text { hands, wrists, feet }\end{array}$ & \\
\hline Slow & Few & Large & Severe & Persistent & $\begin{array}{l}\text { Persistent hydrar- } \\
\text { throsis of knee, } \\
\text { other joints mild }\end{array}$ & \\
\hline Rapid & Few & Small & Moderate & Transient & $\begin{array}{l}\text { Remission } 18 / 12 \\
\text { Relapse } 1948 \\
\text { many joints }\end{array}$ & \\
\hline Slow & Few & Both & Severe & Subsiding & $\begin{array}{l}\text { Residual defor- } \\
\text { mities of } R \text {. knee } \\
\text { and three fingers }\end{array}$ & \\
\hline Rapid & Many & Both & Severe & Persistent & $\begin{array}{l}\text { Gradually subsided } \\
\text { in } 12 \text { years }\end{array}$ & \\
\hline Slow & Many. & Both & Moderate & Intermittent & $\begin{array}{l}\text { Residual defor- } \\
\text { mities of wrists, } \\
\text { fingers, feet }\end{array}$ & \\
\hline Rapid & Many & Large & Severe & Resolving & $\begin{array}{l}\text { Painful swelling of } \\
\text { elbows, other } \\
\text { joints fair }\end{array}$ & \\
\hline Medium & Many & Both & Severe & $\begin{array}{l}\text { Slowly } \\
\text { resolving }\end{array}$ & $\begin{array}{l}\text { Pain in R. knee } \\
\text { only. Residual } \\
\text { deformity of } \\
\text { fingers }\end{array}$ & \\
\hline Rapid & Few & Small & Moderate & Transient & $\begin{array}{l}\text { Remission in } 18 / 12 \\
\text { Transient pains } 10 \\
\text { yrs. Relapse 1948, } \\
\text { many joints }\end{array}$ & \\
\hline Rapid & Many & Both & Severe & Persistent & $\begin{array}{l}\text { Pain and stiffness } \\
\text { in many joints. } \\
\text { No acute inflam- } \\
\text { mation. }\end{array}$ & \\
\hline
\end{tabular}




\begin{tabular}{|c|c|c|c|c|c|c|}
\hline \multirow{2}{*}{$\begin{array}{l}\text { Case } \\
\text { No. }\end{array}$} & \multirow{2}{*}{$\begin{array}{l}\text { Sex and } \\
\text { Age (yrs) }\end{array}$} & \multicolumn{3}{|c|}{ Injury } & \multirow{2}{*}{$\begin{array}{l}\text { Latent } \\
\text { Period }\end{array}$} & \multirow[b]{2}{*}{ Order } \\
\hline & & Joint & Date & Nature & & \\
\hline 28 & $\begin{array}{l}M \\
43\end{array}$ & L. ankle & 1937 & Severe sprain & $2 \mathrm{yrs}$ & 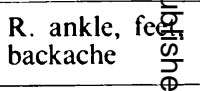 \\
\hline 29 & $\begin{array}{l}F \\
33\end{array}$ & R. elbow & 1933 & $\begin{array}{l}\text { Fall; ulnar } \\
\text { lesion }\end{array}$ & $2 / 12$ & 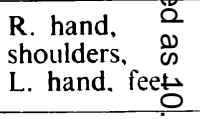 \\
\hline 30 & $\begin{array}{l}\mathbf{F} \\
28\end{array}$ & $\begin{array}{l}\text { Lumbar } \\
\text { spine }\end{array}$ & 1935 & $\begin{array}{l}\text { Fall from } \\
\text { horse }\end{array}$ & $10: 12$ & $\begin{array}{l}\text { Wrists, fingers, } \\
\text { R. shoulder, } \\
\text { R. foot }\end{array}$ \\
\hline 31 & $\begin{array}{r}M \\
8\end{array}$ & L. knee & 1908 & Fall & 8,12 & $\begin{array}{l}\text { L. foot, } \overrightarrow{0} \\
\text { R. knee, } \dot{\omega} \\
\text { R. foot, hip }\end{array}$ \\
\hline 32 & $F_{2 \frac{1}{2}}$ & L. knee & 1925 & $\begin{array}{l}\text { Pushed; } \\
\text { fall }\end{array}$ & $6 / 12$ & 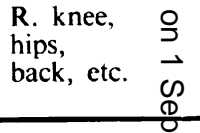 \\
\hline
\end{tabular}

variation in rate of spread, intensity of inflammation, and number of joints involved. This variability renders difficult the comparison of a small series with one seventeen times larger; but the traumatic cases are not perceptibly more or less severe than the others, either in intensity of inflammation or in the number of joints involved (see Columns 6 to 10, Table II).

Order of Joint Involvement: Symmetry.-More than half of the total cases of rheumatoid arthritis were symmetrical from the beginning and chiefly involved small joints. This was also the experience of Short and Bauer (1948) and Egelius and others (1949). In those caused by monarticular trauma, however, the disease must be asymmetrical at the beginning, and large joints are usually involved (Table III), but in most cases it becomes symmetrical early in its course.

In thirteen out of thirty unilateral cases-excluding the two spinal injuriesthe second joint involved was the opposite fellow of the injured one, and in twelve

TABLE III

INJURED JOINT IN TRAUMATIC RHEUMATOID ARTHRITIS

\begin{tabular}{|c|c|c|}
\hline Joint & Present Series & Other Cases* \\
\hline $\begin{array}{l}\text { Knee } \\
\text { Wrist } \\
\text { Elbow } \\
\text { Foot } \\
\text { Hand } \\
\text { Ankle } \\
\text { Back } \\
\text { Shoulder }\end{array}$ & $\begin{array}{r}14 \\
4 \\
4 \\
3 \\
3 \\
2 \\
2 \\
0\end{array}$ & $\begin{array}{r}14 \\
7 \\
1 \\
2 \\
1 \\
10 \\
0 \\
1\end{array}$ \\
\hline Total .. & 32 & 36 \\
\hline
\end{tabular}

* In many recorded cases this detail has not been supplied. 
continued

\begin{tabular}{|c|c|c|c|c|c|c|}
\hline \multirow{2}{*}{$\frac{\text { ead }}{\text { Rate }}$} & \multicolumn{4}{|c|}{ Involvement of Joints } & \multirow{2}{*}{ Later History } & \multirow{2}{*}{ Remarks } \\
\hline & Number & Size & Intensity & Duration & & \\
\hline very slow & Few & Large & Severe & Persistent & $\begin{array}{l}\text { Ankles still pain- } \\
\text { ful and swollen }\end{array}$ & \\
\hline Slow & Few & Small & Moderate & Persistent & $\begin{array}{l}\text { Nodules on } \\
\text { deformed finger- } \\
\text { joints }\end{array}$ & \\
\hline Slow & Few & Large & Severe & Persistent & $\begin{array}{l}\text { Activity in } L \text {. } \\
\text { wrist and } R \text {. } \\
\text { shoulder, anky- } \\
\text { losis of } R \text {. wrist }\end{array}$ & \\
\hline Rapid & Many & Large & Severe & Ankylosing & $\begin{array}{l}\text { Hips, spine, and } \\
\text { many other joints } \\
\text { ankylosed }\end{array}$ & \\
\hline Rapid & Many & Large & Severe & Ankylosing & $\begin{array}{l}\text { Hips, spine, and } \\
\text { many other joints } \\
\text { ankylosed }\end{array}$ & \\
\hline
\end{tabular}

the second appearance of rheumatic disease was the simultaneous involvement of symmetrical joints (both hands, both wrists, etc.).

A normal joint recovers from traumatic synovitis. In the establishing of polyarthritis after trauma, therefore, there are two unusual features:

(i) failure of injured joint to recover,

(ii) spread of effects to other joints.

Failure of Injured Joint to Recover.-This is the result of the interaction of two factors:

(i) overuse of injured joint;

(ii) disturbed joint physiology.

Over-use of Joint.-Rydén found that fourteen of his nineteen patients caused further damage by continuing at work with the joint painful and swollen, or by returning to work before complete recovery.

In Case 10 of the present series the knee, though painful, did not swell until the patient tried to work a month after the injury. In Cases $2,3,4,6,8,12,13$, and several others, normal activity was pursued after the injury. Physiological use of a painful and swollen joint imposes a strain on it, and any movement of inflamed synovial tissues amounts to trauma. Thus a vicious circle might set in; but most injured joints recover even when used a good deal, and another factor is required to maintain the diseased state.

Disturbed Joint Physiology.-Bennett (1943) pointed out that the persistence of hydrarthrosis after trauma indicates that the joint physiology has been fundamentally disturbed. In the hypersecretion of fluid, disordered reflexes play a large part (Leriche, 1928; Pétrignani, 1932).

Spread of Effects to Other Joints.-Rydén believed that occupational strain of the damaged joint, combined with a constitutional factor (bacterial allergy), was responsible for the general spread. And indeed there is evidence that further articular damage plays a part. The general spread took place in Cases 16 and 18 
immediately after the knee joints had been manipulated for " slipped cartilage", and in Case 22 after the scaphoid bone had been drilled for non-union. In a patient reported by Ropes and Bauer (1945), the ankle and the opposite knee swelled after a semi-lunar cartilage had been removed at operation.

The Constitutional Factors. - Of these we have no knowledge in this disease, apart from

(i) the undoubted predisposing influence of heredity (see Cases 13, 16),

(ii) the astonishing effect of cortical hormones-which are not themselves deficient in the body (Hench and others, 1950).

To say, " he has the disease, therefore he must have been predisposed ", is not valid reasoning; such a non sequitur could be applied to cancer, tuberculosis, or almost any other disease; each malady has been called constitutional while its cause was unknown. According to Hunter (1835):

Perhaps there is no term so vague or so undetermined in the mind as the term constitutional. Universal action of every kind may be called constitutional, even when arising from some local cause.

Eight of the 32 patients were over 50 years of age before the occurrence of the accident which brought on the disease. Case 4 had lived for 71 years without rheumatism, but after an injury her knee remained painful and swollen for 5 months before the second knee became involved; then the spread was more rapid. This history does not suggest a permanent constitutional defect, awaiting its opportunity to strike, but that the factor which favoured the spread of the disease was not present until 5 months after the injury.

This factor is probably a late change in the organism; an induced, and possibly transient, state of receptiveness which allows the disorder to spread and become firmly established. If the disease were truly allergic we should expect the joints to be picked out in irregular fashion; but on inquiry we find that it has a remarkable preference for the symmetrically opposite joint (see Table IV). For the same reason, it cannot be due to any material (neoplastic, infective, or chemical) carried by the blood or the lymph stream.

TABLE IV

SYMMETRICAL SPREAD OF TRAUMATIC RHEUMATOID ARTHRITIS

\begin{tabular}{|c|c|c|c|}
\hline Author and Date & & $\begin{array}{l}\text { No. of Cases in which } \\
\text { Details were Given }\end{array}$ & $\begin{array}{l}\text { No. in which First Spread } \\
\text { was Symmetrical }\end{array}$ \\
\hline Copeman (1936) & & 2 & 0 \\
\hline Davison and others (1950) & 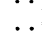 & 1 & 0 \\
\hline Edström (1942) & .. & 4 & 4 \\
\hline Jonsson and Berglund (1949) & 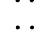 & 1 & $\mathbf{0}$ \\
\hline Kuhns (1945) $\quad . . \quad \ldots$ & $\therefore$ & 1 & $\mathbf{0}$ \\
\hline Myers (1951) & .. & 1 & 0 \\
\hline Nissen and Spencer (1934) & $\ldots$ & 1 & 1 \\
\hline Pickard (1947) & .. & 1 & 1 \\
\hline Ropes and Bauer (1945) .. & .. & 1 & 0 \\
\hline Rydén (1943) & $\ldots$ & 19 & 6 \\
\hline Present Series & 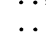 & $30 *$ & 13 \\
\hline Total & $\ldots$ & 62 & 25 \\
\hline
\end{tabular}

* In two cases the back (a mid-line structure) was injured. 
In the precipitation of rheumatoid arthritis by damage to a joint, there is no analogy with the lighting up of septicaemia by injury. Organisms gain a foothold in the damaged tissues, and later spread by the blood stream, resistance to the spread of infection depending on serological developments. In polyarthritis no one now believes that organisms are present in the joints or that its spread is resisted by antibodies in the serum.

The Neural Factor.-If the spread were entirely fortuitous, it would be symmetrical in perhaps three cases out of the thirty, instead of in thirteen. (Other writers have recorded the same preference for the opposite joint, see Table IV.) And in twelve of the remaining nineteen cases the first spread was to two symmetrical joints. Since symmetry in a disease can suggest only the involvement of nervous channels, it appears that the constitutional factor in traumatic rheumatoid arthritis involves a disturbance of the central nervous system.

Paget (1879), who wondered about the symmetry of many rheumatic lesions, postulated at first an exact similarity of chemical composition which rendered symmetrical structures equally attractive to circulating toxins. But he changed his opinion when he saw that the appearance of the lesions on the second side was often delayed for months or years. He wrote:

It is clearly probable that the symmetrical distribution of diseases on corresponding portions of the extremities should depend on central nervous connections rather than on any assumed identity of chemical composition.

In a previous series of articles (Kelly, 1945, 1946a, b), I presented a neural theory of rheumatic disease. This was not a new theory but a very old one which had been held by all the great clinicians of the 19th century (Garrod, 1888); it had never been disproved, but had been abandoned when everyone became convinced that the new science of bacteriology was about to solve every problem. Evidence in favour of the neural theory continues to accumulate; relevant articles are listed in the Additional Bibliography, and I can only repeat my previous conclusion:

The verification of this hypothesis depends upon the painstaking and careful observation of mild and transient cases of somatic pain, and of early cases of rheumatic disease.

Traumatic rheumatoid arthritis, which gives us an opportunity of observing the early spread of the disease from a single lesion, may also contribute in striking fashion to the verification of the neural hypothesis.

\section{Summary}

(1) In 32 cases of rheumatoid arthritis, in which the only visible causative factor was injury to a single joint, the clinical picture of the established disease did not differ perceptibly from the usual.

(2) Before spreading to other joints, the disease was monarticular for periods up to two years. It went first to the opposite joint in thirteen cases, and simultaneously to two symmetrical joints in twelve.

(3) The persistence of chronic arthritis in an injured joint depends on two factors:

(i) further damage to the joint by overstrain;

(ii) reflex disturbance of joint physiology. 
(4) The commencement of spread frequently followed overstrain or further damage to the injured joint; symmetry suggests that the change is propagated through nervous channels.

(5) It is concluded that the constitutional factor which favours the spread of the disease is not a permanent defect but a late disturbance of the nervous system, induced by impulses from the damaged tissues.

Bennett, G. A. (1943). Clinics, 1, 1448.

\section{REFERENCES}

Bille, S. V. (1948). Nord. med, 37, 307. (Abstr. Wld. Med., 4, 311.)

Edström, G. (1942). Acta med. Scand., 111, 150.

Egelius, N., Havermark, N. G., and Jonsson, E. (1949). Annals of the Rheumatic Diseases, 8, 217.

Finney, J. O., Boland, E. W., and Hench, P. S. (1947). Ibid., 6, 91.

Garrod, A. E. (1888). Med.-Chir. Trans., 71, 89.

Hench, P. S., Bauer, W., Holbrook, W. P., Engleman, E. P., and Steinbrocker, O. (1950). Annals of the Rheumatic Diseases, 9, 407.

Hunter, J. (1835). " The Works of John Hunter, F.R.S.", vol. 1, p. $340 . \quad$ London.

Jonsson, E., and Berglund, K. (1949). Acta med. scand., 135, 255.

Kelly, M. (1945). Annals of the Rheumatic Diseases, 5, 1.

- (1946a). Ibid., 5, 69.

- (1946b). Ibid., 5, 61.

—_ (1948). Med. J. Aust., 2, 309.

- (1949). Ibid., 2, 528.

-_- (1951). Ibid., 2, 197.

Klinge, F. (1934). Acta rheumatol., 6, 2 (cited by Rydén, 1943).

Leriche, R. (1928). J. Bone Jt Surg., 10, 492.

Paget, J. (1879). " Clinical Lectures and Essays ”, 2nd ed. Longmans, London.

Pétrignani, R. (1932). Rev. Orthopéd., 19, 101.

Pickard, N. S. (1947). Arch. int. Med., 80, 771.

Ropes, M. W., and Bauer, W. (1945). New Engl. J. Med., 233, 592.

Rydén, E. (1943). Acta med. scand., 114, 442.

Short, C. L., and Bauer, W. (1948). New Engl. J. Med., 238, 142.

Smith, M. (1932). Ibid., 206, 103, 160, 211.

\section{Additional Bibliography of Relevant Articles}

\section{A. Traumatic Rheumatoid Arthritis}

Campbell, W. C. (1936). J. Lab. clin. Med., 22, 30.

Cecil, R. L., and Kammerer, W. H. (1951). Amer. J. Med., 10, 438.

Charcot, J. M. (1881). "Clinical Lectures on Senile and Chronic Diseases", trans. W. S. Tuke. New Sydenham Society, London.

Copeman, W. S. C. (1936). Rep. chron. rheumat. Dis., 2, 24.

Davison, R., Koets, P., Snow, W. G., and Gabrielson, L. G. (1950). Arch. int. Med., 85, 365.

Kuhns, J. G. (1945). New Engl. J. Med., 232, 128.

Lockie, L. M., and Norcross, B. M. (1948). Pediatrics, 2, 694.

Matz, P. B. (1933). New Engl. J. Med., 209, 547, 597, 639.

Myers, G. N. (1951). Annals of the Rheumatic Diseases, 10, 32.

Nissen, H. A., and Spencer, K. A. (1934). New Engl. J. Med., 210, 147.

\section{B. Neural Theory}

Barceló, P., and Serra Peralba, A. (1949). Rev. rhum., 16, 493.

Bates, J. (1949). Brit. med. J., 1, 710.

Bayles, T. B., Judson, W. E., and Potter, T. A. (1950). J. Amer. med. Ass., 144, 537.

Buxton, St. J. D. (1924). Proc. roy. Soc. Med., 18, Sect. Orthop. 15.

Cuatrecasas, J. (1949). Rev. Argent. Reum., 14, 144.

De Preux, T. (1949). Rev. rhum., 16, 347.

Echols, D. H., and Colclough, J. A. (1947). J. Amer. med. Ass., 134, 1476.

Euzière, J., Pages, P., Lafon, R., Mirouze, J., and Salvaing, J. (1949). Rev. rhum., 16, 26, 30.

Gillman, T., and Gillman, J. (1946). Amer. J. med. Sci., 211, 448.

Giraud, G., and Bert, J. M. (1949). Rev. rhum., 16, 14. 
Good, M. G. (1951). Brit. J. phys. Med., 14, 1, 56.

Haas, A. M. Lorentz de (1941). Acta psychiat. et neurol., 16, 405.

Kohler, W. (1950). Deut. med. Wchschr., 75, 1070.

Lichtwitz, L. (1944). “Pathology and Therapy of Rheumatic Fever.” Heinemann, London.

Martin, E. (1944). Praxis, 33, 315.

Morrison, L. R., Short, C. L., Ludwig, A. O., and Schwab, R. S. (1947). Amer. J. med. Sci., $214,33$.

Ravault, P., Thiers, H., and Berthier, L. (1949). Rev. rhum., 16, 1.

Rimbaud, L., Serre, H., and Passouant, P. (1947). Bull. soc. méd. Hôp. Paris, 63, 435.

Scheiffarth, F. (1950). Z. Rheumaforsch., 9, 1, 93, 156.

Steinbrocker, O., Spitzer, N., and Friedman, H. H. (1948). Ann. int. Med., 29, 22.

Stone, K. (1947). "Diseases of the Joints and Rheumatism." Heinemann, London.

Thurel, R., and Guillaume, J. (1936). Rev. neurol., 69, 56.

Wyburn-Mason, R. (1950). " Trophic Nerves." Kimpton, London.

Zoboli, P. (1947). Bol. soc. med. chir. Modena, 47, 91. (Internat. Abstr. Surg., 1948, 87, 291.)

\section{Traumatisme Monoarticulaire et Arthrite Rhumatismale}

\section{RÉSUMÉ}

(1) Dans 32 cas d'arthrite rhumatismale, dans lesquels le seul facteur causatif visible était un traumatisme d'une seule articulation, le tableau clinique de la maladie à la période d'état ne sortait pas sensiblement de l'ordinaire.

(2) Avant de s'étendre aux autres articulations, toutefois, la maladie demeurait monoarticulaire pendant des périodes allant jusqu'à deux ans. Dans 13 cas elle passa d'abord à l'articulation du coté opposé et, dans 12 cas, simultanément, à deux articulations symétriques.

(3) La persistance de l'arthrite chronique dans une articulation lésée dépend de deux facteurs:

(i) altération subséquente de l'articulation par surmenage;

(ii) troubles réflexes de la physiologie articulaire.

(4) Le début de l'extension suivait souvent le surmenage ou des lésions ultérieures de l'articulation qui avait subi le traumatisme; l'existence de la symétrie fait penser à la propagation des altérations par des voies nerveuses.

(5) On conclut que le facteur constitutionnel qui favorise l'extension de la maladie n'est pas. un défaut permanent mais un dérangement tardif du système nerveux, provenant de la stimulation originant des tissus endommagés.

\section{Traumatismo Monoarticular y la Artritis Reumatoide}

Sumario

(1) En 32 casos de artritis reumatoide, en los cuales el único factor causante visible fué un traumatismo en una sola articulación, el cuadro clínico de la enfermedad establecida no se distinguía perceptiblemente de la forma usual.

(2) Antes de extenderse a otras articulaciones, sin embargo, la enfermedad se mantuvo monoarticular hasta por dos años. Atacó primeramente la articulación opuesta en trece casos y, simultáneamente, a dos articulaciones simétricas, en doce.

(3) La persistencia de artritis crónica en una articulación traumatizada depende de dos factores:

(i) daño subsiguiente por fatiga excesiva de la articulación;

(ii) disturbios reflejos de la fisiología articular.

(4) La extensión del mal solía iniciarse despuès de la fatiga excesiva o de daño subsiguiente causado a la articulación afectada; la existencia de la simetría sugiere que los cambios mórbidos se propagan a través de las vías nerviosas.

(5) Se concluye que el factor constitucional que favorece la extensión de la enfermedad no es un defecto permanente sino un disturbío tardío del sistema nervioso, inducido por impulsos procedentes de los tejidos dañados. 